\title{
Osteoinduction in human fat-derived stem cells by recombinant human bone morphogenetic protein-2 produced in Escherichia coli
}

\author{
Paulo C. Bessa · A. J. Pedro $\cdot$ B. Klösch $\cdot$ A. Nobre • \\ M. van Griensven $\cdot$ R. L. Reis $\cdot$ M. Casal
}

Received: 10 May 2007/Revised: 16 July 2007/ Accepted: 17 July 2007

(C) Springer Science+Business Media B.V. 2007

\begin{abstract}
Bioactive recombinant human bone morphogenetic protein-2 (rhBMP-2) was obtained using Escherichia coli pET-25b expression system: $55 \mathrm{mg}$ purified rhBMP-2 were achieved per g cell dry wt, with up to $95 \%$ purity. In murine $\mathrm{C} 2 \mathrm{C} 12$ cell line, rhBMP-2 induced an increase in the transcription of Smads and of osteogenic markers Runx2/Cbfa1 and Osterix, measured by semi-quantitative RT-PCR. Bioassays performed in human fat-derived stem cells
\end{abstract}

P. C. Bessa - A. J. Pedro - R. L. Reis

3B's Research Group - Biomaterials,

Biodegradables and Biomimetics,

Department of Polymer Engineering,

University of Minho,

Campus de Gualtar, 4710-057 Braga, Portugal

e-mail: rgreis@dep.uminho.pt

P. C. Bessa · A. J. Pedro · R. L. Reis

PT Government Associated Laboratory, IBB - Institute for Biotechnology and Bioengineering, 4710-057 Braga, Portugal

P. C. Bessa $(\varangle) \cdot$ A. Nobre $\cdot$ M. Casal CBMA - Molecular and Environmental Biology Centre/Biology Department, University of Minho,

Campus de Gualtar, 4710-057 Braga, Portugal

e-mail: paulo.bessa@dep.uminho.pt

URL: www.3bs.uminho.pt

B. Klösch · M. van Griensven

Ludwig Boltzmann Institute for Experimental and Clinical Traumatology, Donaueschingenstrasse 13, 1200

Vienna, Austria showed an increased activity of the early osteogenic marker, alkaline phosphatase, and the absence of cytotoxicity.

Keywords Bone morphogenetic protein-2 .

Recombinant protein purification .

Stem cells . Tissue engineering

\section{Introduction}

Bone morphogenetic proteins (BMPs) are a group of cytokines from the TGF- $\beta$ superfamily (Wozney et al. 1988) with a strong ability to induce bone and cartilage formation (Urist 1965; Reddi 1998). BMPs have been used as powerful osteoinductive components in several late-stage tissue engineering products for bone grafting (Westerhuis et al. 2005).

During the process of bone healing, signals from BMPs trigger the differentiation of stem cells into bone-forming cells that are recruited to the site of injury (Reddi 1981). BMPs bind to serinethreonine kinase cell receptors and mediate their signals through Smad-related cascades and Smadindependent pathways (Derynck 2001; Shi and Massague 2003). Signal is regulated by different factors such as binding to cell surface receptors (Kirsch et al. 2000; Sebald et al. 2004), formation of BMP-heterodimers (Israel et al. 1996), presence of antagonists such as Noggin (Groppe et al. 2002), cross-talk with other pathways (Miyazono et al. 
2005) and the presence of a heparin binding domain in the $N$-terminal region of BMP-2 which provides anchorage of the cytokine to the extracelular matrix (Ruppert et al. 1996; Kubler et al. 1999; Wurzler et al. 2004).

Currently, most BMPs are obtained from mammalian cell cultures in low yields (Wang et al. 1990; Israel et al. 1992) or from bacteria inclusion bodies after time-consuming refolding procedures (Kubler et al. 1998; Vallejo et al. 2002; Long et al. 2006). Aiming to circumvent the disadvantages of the previously reported methods, we have developed a novel approach for the production of high amounts of soluble and pure rhBMP-2, with a bioactivity verified in murine myoblast $\mathrm{C} 2 \mathrm{C} 12$ cell line as well as in human fat-derived adult stem cells.

\section{Materials and methods}

\section{Cloning of rhBMP-2}

The sequence coding for the mature (bioactive) domain of human BMP-2 was obtained from a bacterial clone (Sanger Institute, UK), containing locus 20p12.1-13 of chromosome 20 of human genome, which includes the entire gene for human BMP-2 (clone ref. RP5-859D4). According to the data in the Human Genome Project (http://www.ensembl.org/homo_sapiens), the entire human BMP-2 gene (Ensembl gene OTTHUMG00000031833) includes three exons and two introns with the open reading frame located on exons 2 and 3. By consulting UniProtKB/Swiss-Prot, human BMP-2 protein (P12643) mature domain consists of amino acids 283-396, which is obtained after cleavage from propeptide (Hillger et al. 2005). The region corresponding to the mature domain is located solely in exon 3 and, for this reason, we have cloned directly by PCR this sequence from the above mentioned clone (Fig. 1A). Mature domain was amplified by PCR using primers 5'-CGG GAT CCA CAA GCC AAA CAC AAA CAGC-3' (forward primer) and 5'-CCC TCG AGG CGA CAC CCA CAA CCC TC-3' (reverse primer). The nucleotides for cleavage by BamHI and XhoI in forward primer and reverse primers, respectively, are underlined the codons corresponding to amino acids 283
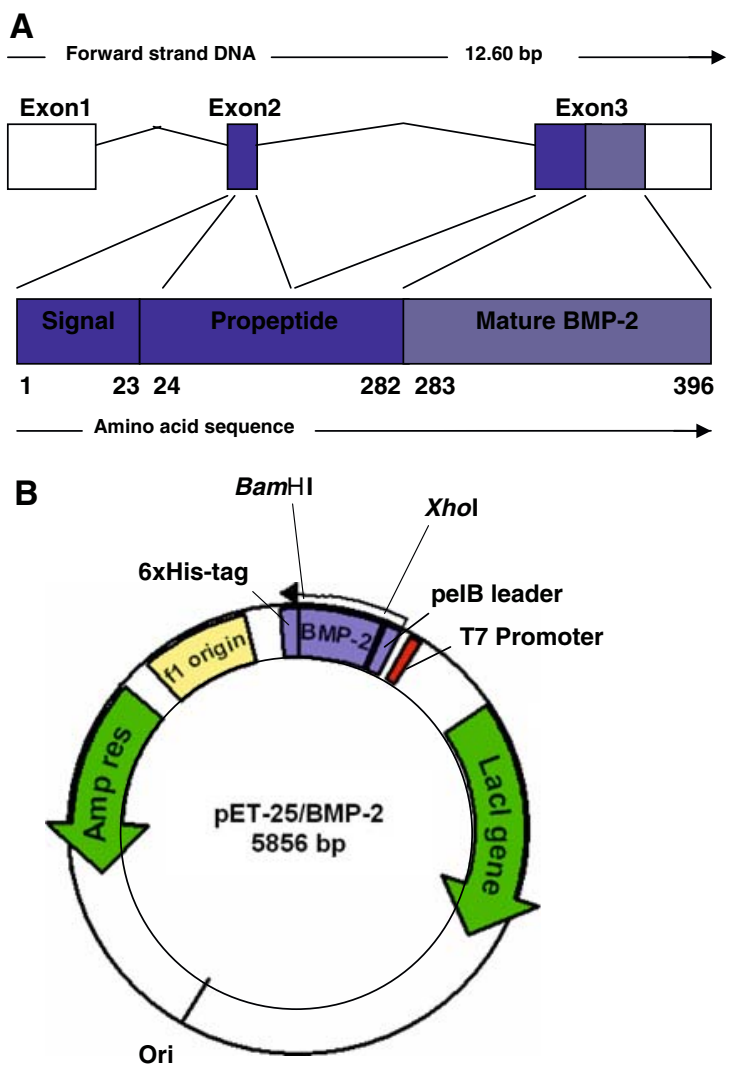

Fig. 1 Strategy used for cloning the mature domain of human bone morphogenetic protein-2. (A) BMP-2 gene contains three exons represented by boxes and two introns corresponding to the lines. Coding region is represented by black boxes located in exon 2 and 3. The mature domain of human BMP-2 protein is entirely located on exons 3 correspondent to amino acids 283-396. (B) Construction of vector pET-25b/rhBMP-2 for expression of human BMP-2 in E. coli. The mature BMP-2 was cloned into the vector pET-25b together with its own leader sequence and 6-histidine tag for purification

and 396 are represented in bold. PCR-product was first cloned into pGEM T-Easy vector (Promega, USA) and then subcloned in a pET-25b vector (Novagen, USA) via the two restriction sites, BamHI and XhoI (plasmid pET-25b/rhBMP-2), that was used to transform E. coli BL21(DE3) strain (Invitrogen, UK). DNA cloning and manipulation were performed according to standard protocols (Sambrook et al. 1989). The integrity of cloned PCR products was verified by DNA sequencing (Sanger et al. 1977) using ABI PRISM310 Genetic Analyzer. 
Expression of rhBMP-2 in E. coli growing in a bioreactor

Transformed E. coli BL21(DE3) strain with pET$25 \mathrm{~b} / \mathrm{rhBMP}-2$ or $\mathrm{pET}-25 \mathrm{~b}$ vectors were picked and transferred into $50 \mathrm{ml}$ Luria Bertani (LB) media with $50 \mu \mathrm{g}$ ampicillin $/ \mathrm{ml}$ and incubated at $37^{\circ} \mathrm{C}$ for $1-2 \mathrm{~h}$. Pre-cultures were then transferred to a pre-autoclaved 21 Bioflo110 bioreactor (New Brunswick Scientific, USA) containing LB media with $50 \mu \mathrm{g}$ ampicillin/ml and cultured at $37^{\circ} \mathrm{C}$ to an $\mathrm{OD}_{600}$ of 1 when $1 \mathrm{mM}$ IPTG was then added and temperature lowered to $25^{\circ} \mathrm{C}$. During the entire process, aeration was kept at $21 / \mathrm{min}$ and an agitation cascade between $300 \mathrm{rpm}$ and $1,000 \mathrm{rpm}$ was selected in order to maintain minimum dissolved oxygen levels at $30 \%$ of saturation. The $\mathrm{pH} 7.4$ was kept constant using $\mathrm{NH}_{4} \mathrm{OH}$ $(30 \%, v / v)$ and $\mathrm{H}_{3} \mathrm{PO}_{4}(5 \mathrm{M})$ pumped into the bioreactor vessel. Biomass was collected by centrifugation $\left(4,000 \mathrm{~g}, 20 \mathrm{~min}, 4^{\circ} \mathrm{C}\right)$, washed once with PBS and stored at $-20^{\circ} \mathrm{C}$.

\section{Purification of rhBMP-2}

Frozen bacteria were resuspended in lysis buffer (20 mM sodium phosphate buffer, $0.5 \mathrm{M} \mathrm{NaCl}$, $1 \mathrm{mg} / \mathrm{ml}$ lysozyme), with inhibitor of proteases (Complete Mini EDTA-free, Roche). Bacteria were ultrasonicated 4 times for $15 \mathrm{~s}$ with intervals of $1 \mathrm{~min}$ on ice and supernatant and pellet fractions collected by centrifugation $\left(4,000 \mathrm{~g}, 30 \mathrm{~min}, 4^{\circ} \mathrm{C}\right)$. The pellet was then incubated overnight in solubilization buffer (phosphate/saline buffer, $40 \mathrm{mM}$ imidazole, $0.7 \mathrm{M}$ L-arginine, $\mathrm{pH} 11.0$ ) at $18^{\circ} \mathrm{C}$ with gentle stirring and the supernatant containing soluble rhBMP- 2 collected after centrifugation $\left(4,000 \mathrm{~g}, 4^{\circ} \mathrm{C}\right.$, and $\left.30 \mathrm{~min}\right)$. The supernatant was adjusted to $\mathrm{pH} 8.5$ with $0.1 \mathrm{M} \mathrm{HCl}$ and applied to a pre-equilibrated HisTrap chromatography column (Amersham). Briefly, column was equilibrated with 5 column volumes of sodium phosphate buffer containing $40 \mathrm{mM}$ imidazole. The column was washed extensively with $60-80 \mathrm{ml}$ of sodium phosphate buffer containing $80 \mathrm{mM}$ imidazole and sample eluted in $15 \mathrm{ml}$ of sodium phosphate buffer containing $500 \mathrm{mM}$ imidazole. The flow rate was $5 \mathrm{ml} / \mathrm{min}$ during the whole procedure. Samples were analyzed by SDS-PAGE and Western blotting. Imidazole was removed by buffer exchange to phosphate buffer saline with use of a HiTrap desalting column (Amersham) prior to bioactivity tests.

Analytical detection of rhBMP-2 by reducing and non-reducing SDS-PAGE and Western-blot

Protein samples were mixed with SDS-PAGE loading buffer and heated at $95^{\circ} \mathrm{C}$ for $5 \mathrm{~min}$. Samples were separated by using hand-cast $10-12 \%$ SDS-PAGE gels in reducing or non-reducing conditions. Reducing conditions included the use of SDS-PAGE loading buffer with $5 \%(\mathrm{v} / \mathrm{v}) \beta$-mercaptoethanol as reducing agent. Coomassie Blue-R or silver staining was used for visualization and staining of gels. Samples were then electro-transferred (semi-dry Western-blot transfer) to a nitrocellulose membrane at $400 \mathrm{~mA}, 10 \mathrm{~V}$ for $30 \mathrm{~min}$. The membranes were blocked with $2 \%(\mathrm{w} / \mathrm{v})$ BSA in PBS-T buffer (PBS, $0.05 \%$ Tween 20) and incubated either with peroxidase conjugated anti-His antibody (Sigma) diluted 1:5,000 or rabbit anti-human BMP-2 polyclonal primary antibody (AbD Serotec) diluted 1:5,000 followed by mouse anti-rabbit peroxidase conjugated secondary antibody (Amersham) diluted 1:30,000. Image detection was performed with ChemiDoc XRS and Quantity One software (BioRad).

\section{Bioactivity tests}

$\mathrm{C} 2 \mathrm{C} 12$ cells were seeded at $10^{5}$ cells $/ \mathrm{ml}$ per well in a 24-well plate, attached overnight in Dulbecco's modified Eagle's medium (DMEM) with $1 \%$ (v/v) fetal calf serum and no antibiotics, at $37^{\circ} \mathrm{C}$ with $5 \%$ $\mathrm{CO}_{2}$ in a humidified environment. Cells were incubated for 5 days with rhBMP-2 purified by the method described above and a commercial rhBMP2 (Wyeth, USA) used as control. Primary cultures of human fat tissue derived stem cells (Malafaya et al. 2005; Zuk et al. 2002) were seeded at $10^{5}$ cells $/ \mathrm{ml}$ per well in a 24-well plate and attached overnight in DMEM with $50 \mu \mathrm{g}$ ascorbic acid $/ \mathrm{ml}, 10 \mathrm{mM}$ $\beta$-glycerophosphate, $100 \mathrm{U}$ penicillin $/ \mathrm{ml}, \quad 100 \mu \mathrm{g}$ streptomycin $/ \mathrm{ml}$ and $10 \%(\mathrm{v} / \mathrm{v})$ fetal bovine serum at $37^{\circ} \mathrm{C}$ in $10 \% \mathrm{CO}_{2}$. Cells were incubated for 14 days with rhBMP-2 purified by our method, with media replacement every 2 days. Alkaline 
phosphatase (ALP) enzymatic activity was determined accordingly to standard procedures (Salgado et al. 2002) after 5 days on $\mathrm{C} 2 \mathrm{C} 12$ cell line cultures and after 3, 7 and 14 days on cell cultures of mesenchymal stem cells. MTS cell viability assay was determined after 3, 7 and 14 days of cell culture in human stem cells (Salgado et al. 2002). For RT-PCR, mRNA of C2C12 cells was extracted after 5 days of cell culture with TriReagent RNA Isolation Reagent (Sigma-Aldrich) and cDNA was synthesized from $4 \mu \mathrm{g}$ total RNA with oligo dT primer (MWG Biotech AG) and AMV reverse transcriptase (Promega). The polymerase chain reaction (PCR) was performed with specific primers for osteogenic markers (Table 1) and with use of a Hot Star Taq Polymerase (Qiagen). Agarose gels were imaged with MultiImage Light Cabinet (Alpha Innotech, USA) and gene expression analyzed with ChemiImage 4400 AlphaEase FC Image Analysis Software (Alpha Innotech, USA) and using polymerase II for normalizing gene expression.

\section{Results}

Cloning, expression and purification of rhBMP-2

The PCR gave a single product of the coding region of human BMP-2, with expected size of $359 \mathrm{bp}$ (data not shown). DNA sequencing revealed a total correspondence to the encoded amino acids (Ensembl gene OTTHUMG00000031833). Figure 1B shows the map of the expression vector pET-25b/rhBMP-2 used for transformation of bacteria. E. coli BL21 (DE3) strain transformants were grown and collected in conditions described in Material and Methods section. After bacteria lysis, rhBMP-2 was found mainly in the pellet (fraction corresponding to bacterial debris) (Fig. 2A). Soluble protein was then recovered with phosphate buffer containing $0.7 \mathrm{M}$ L-arginine, $\mathrm{pH}$ 11.0. Purification procedures revealed that rhBMP-2 was expressed in monomer, dimer and polymer forms visible in Western-blot using antibodies anti-histidine tag and anti-BMP-2. Silver stained SDS-PAGE revealed up to $95 \%$ purity (Fig. 2B). RhBMP-2 stored in $20 \mathrm{mM}$ phosphate sodium, $0.5 \mathrm{M}$ $\mathrm{NaCl}$ was found to be stable over 2 months at $\mathrm{pH}$ range of 7-9 (data not shown).

\section{Biological activity in $\mathrm{C} 2 \mathrm{C} 12$ cells}

Bioassays were performed in murine myoblast C2C12 cell line, by the administration of purified rhBMP-2. Semi-quantitative RT-PCR revealed an increase of expression of early osteoblast differentiation markers after 5 days of cell culture, such as the osteochondral transcription factor Runx $2 / \mathrm{Cbfa} 1$ (by 2 to 3-fold), Smad-1 and -5 (up to 1.5-fold) and osteoblast transcription factor Osterix (up to 1.5-fold).
Table 1 Oligonucleotide primers for semi-quantitative RT-PCR analysis in murine C2C12 cells

\begin{tabular}{|c|c|}
\hline Gene marker & Primer sequence: Sense/Antisense \\
\hline Runx2/Cbfa1 & $\begin{array}{l}5^{\prime} \text {-GCC GCA GTG CCC CGA TTG AGG-3' } \\
5^{\prime} \text {-AGG GAG GGC CTG GGG TTC TGA GG-3' }\end{array}$ \\
\hline Smad-1 & $\begin{array}{l}5^{\prime} \text {-CCC ACC TGC TTA CCT GCC TCC TGA-3' } \\
5^{\prime} \text {-TGG GGT GAA AGC CGT GGT GGT AGT-3' }\end{array}$ \\
\hline Smad-5 & $\begin{array}{l}\text { 5'-AAT GGG CAG AAA AGG CAG TGG ATG-3' } \\
5^{\prime} \text {-AGC GTT GTT GGG TTG GTG GAA AGA-3' }\end{array}$ \\
\hline Osterix & $\begin{array}{l}5^{\prime} \text {-GCA GTG GGG CAG GGC GTT CTA CC-3' } \\
5^{\prime} \text {-GGG GCG GCT GAT TGG CTT CTT CTT-3' }\end{array}$ \\
\hline Osteocalcin & 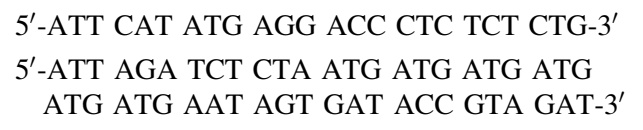 \\
\hline ALP & $\begin{array}{l}5^{\prime} \text {-CAC GCG ATG CAA CAC CAC TCA GG-3' } \\
5^{\prime} \text {-GCA TGT CCC CGG GCT CAA AGA-3' }\end{array}$ \\
\hline Polymerase II & $\begin{array}{l}\text { 5'-TAC ACC CCA GCT TCT CCC AAA TAC-3' } \\
5^{\prime} \text {-AGC TCT TCG CCC TGT TCG-3' }\end{array}$ \\
\hline
\end{tabular}


A

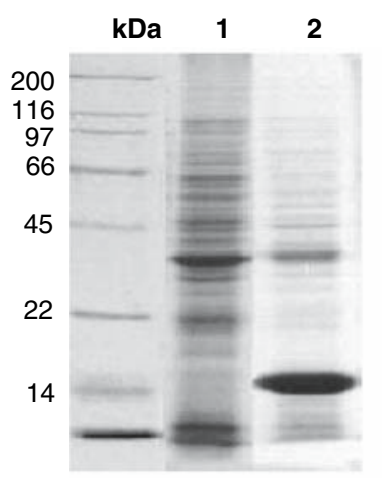

B

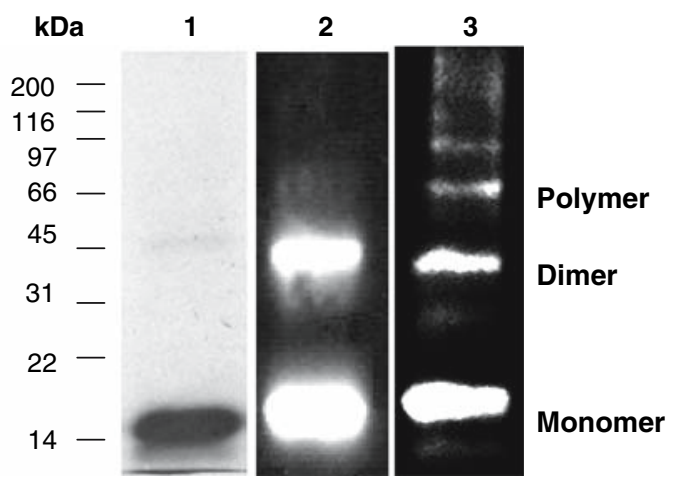

Fig. 2 (A) Coomassie-blue stained SDS-PAGE of crude lysates, pellet fraction, from batch cultivation of transformed E. coli. Lanes 1) pET-25b clone; 2) rhBMP-2/pET-25b clone. Monomer appears as a well-defined band around $17 \mathrm{kDa}$. Molecular weight is in $\mathrm{kDa}$ (Broad Range, BioRad).

In these tests, the levels of ALP mRNA did not changed significantly. Commercial mammalian rhBMP-2 induced markedly Runx2/Cbfa1 by 3-7-fold, Smad-1 and Smad-5 by 2-5 fold, Osterix by 2 to 4 -fold, Osteocalcin by $2-9$-fold and high levels of ALP expression were detected (Fig. 3).

Biological activity in mesenchymal stem cells

RhBMP-2 did not show any significant evidence of cytotoxicity in human mesenchymal stem cells after 2 weeks of cell culture (Fig. 4A). MTS is a viability/ proliferation test and an inverse relationship of toxicity to cells can be assumed. In human primary cultures of fat-derived stem cells, there was an increase in levels of ALP enzymatic activity (Fig. 4B). Data correlates with morphological observations of the cells with optical microscopy (Fig. 5).

\section{Discussion}

A novel and more simple approach has been developed for the production of readily soluble rhBMP-2 using E. coli that, for the first time, is bioactive in human cell cultures. In previous reports, recombinant BMP-2 production was achieved in bacterial inclusion bodies in fairly large amounts ( $\mathrm{Li}$ et al. 1998; Vallejo et al. 2002; Long et al. 2005). However, inclusion bodies require time-consuming steps for
(B) rhBMP-2 purified by affinity chromatography: 1) Silver stained reduced SDS-PAGE, showing the monomer of BMP-2 with significant purity; 2) Western-blot using anti-his tag antibody; 3) Western-blot using anti-BMP-2 antibody. BMP-2 is visible in monomer, dimer and polymer

solubilization and refolding. In our approach, we have achieved expression of rhBMP-2 directly folded in dimer by use of pET-25 expression system which
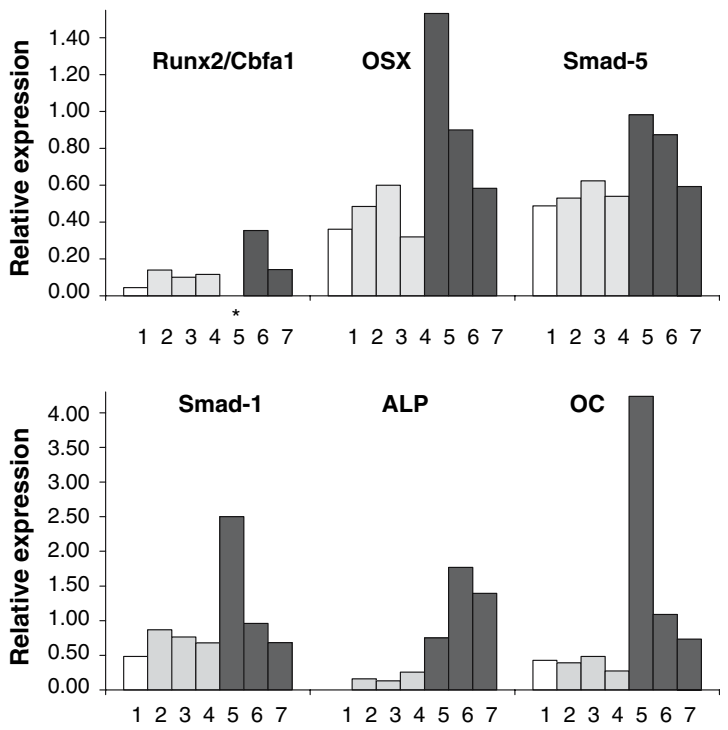

Fig. 3 RT-PCR for genes involved during osteoblast differentiation of $\mathrm{C} 2 \mathrm{C} 12$ cells after 5 days of culture with purified rhBMP-2 and commercial mammalian rhBMP-2 as control. Gene expression was analyzed with ChemiImage 4400 AlphaEase FC Image Analysis Software (Alpha Innotech) and standardized with Polymerase II expression. OSX: osterix; OC: osteocalcin; ALP: alkaline phosphatase. Conditions used: 1) No rhBMP-2; 2) $250 \mathrm{ng} / \mathrm{ml}$; 3) $500 \mathrm{ng} / \mathrm{ml}$; 4) $1,000 \mathrm{ng} / \mathrm{ml}$; 5) $250 \mathrm{ng} / \mathrm{ml}$ commercial preparation; 6) $500 \mathrm{ng} / \mathrm{ml}$ commercial preparation; 7) $1,000 \mathrm{ng} / \mathrm{ml}$ commercial preparation. Data presented are mean values of two independent experiments. (*bioassay was not performed) 
A

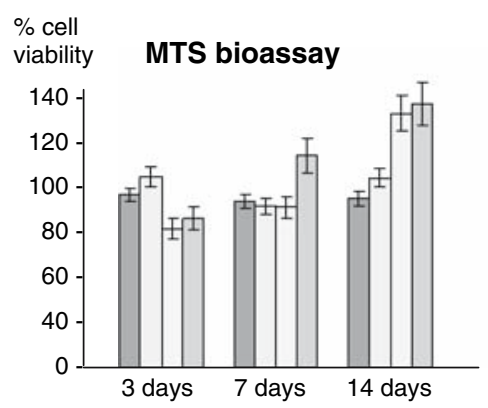

Fig. 4 (A) Tetrazolium salt (MTS) test performed in fat tissue derived human stem cells as a function of rhBMP-2 concentration, after 3, 7 and 14 days of cell culture. Cell viability is expressed in percentage. (B) Bioactivity of rhBMP-

directs production of soluble recombinant protein into periplasmatic space of $E$. coli, thus allowing the formation of disulfide bridges.

Recovery with $0.7 \mathrm{M}$ L-arginine buffer resulted in monomer, dimer and polymer forms adding value to what has been reported by Klösch et al. (2005) and Long et al. (2006). Formation of cysteine bridges is favored at slightly alkaline $\mathrm{pH}$, thus increasing amounts of dimeric rhBMP-2 (Vallejo and Rinas 2004). However, this contribution seems to be the first one to show this method to obtain soluble and dimeric BMP-2 directly upon production. The amount of purified rhBMP-2 was about $55 \mathrm{mg}$ per $\mathrm{g}$ cell dry wt, corresponding to $110 \mathrm{mg}$ purified rhBMP-2 per liter of culture broth.
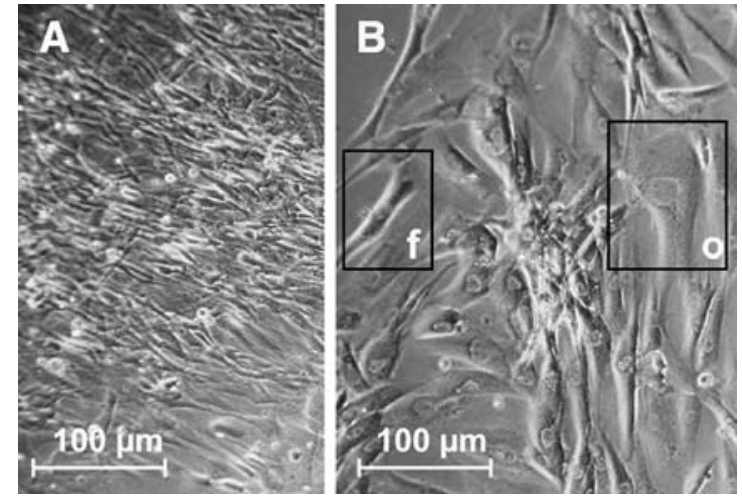

Fig. 5 Cell morphology of fat-derived human stem cells after 10 days of cell culture with A) no growth factor (control) and B) with $500 \mathrm{ng}$ purified $\mathrm{rhBMP}-2 / \mathrm{ml}$ (replacement of growth factor and culture media every 2 days). Fibroblast-like (f) and osteoblast-like (o) morphologies were observed when rhBMP-2 was used on the mesenchymal stem cell primary culture
B

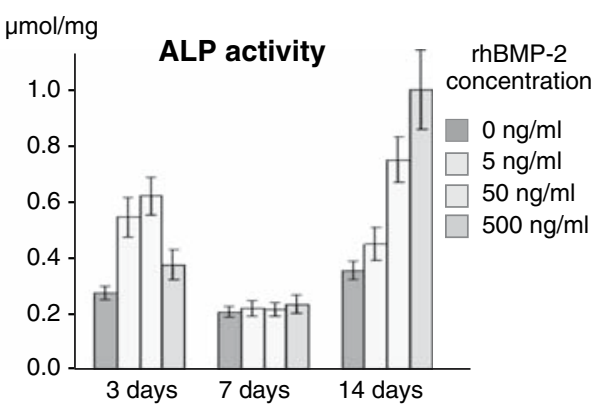

2 as measured by the induction of alkaline phosphatase activity in fat tissue derived human stem cells. ALP activity levels are expressed in $\mu \mathrm{mol}$ ALP per mg of total protein

In previous studies, recombinant BMPs obtained from $E$. coli were tested in murine cells lines $\mathrm{C} 2 \mathrm{C} 12$ (Vallejo et al. 2002; Long et al. 2006), MC3T3-E1 (Klösch et al. 2005) and CH310T1/2 (Yang et al. 2003) or in vivo rodent models (Kubler et al. 1998; Bessho et al. 2000; Hillger et al. 2005). In our case, bioactivity was achieved using primary cultures of human stem cells. Binding of active BMP-2 to cell receptors results in an increase of early markers activated during osteogenic differentiation (i.e., Runx2, Osterix). In human stem cells, rhBMP-2 increased ALP activity and differentiated cells into osteoblast-like morphology. In conclusion, the novel approach described herein shows steps for improving the production of high amounts of readily soluble rhBMP-2 that shows bioactivity in primary human adult stem cells, and can be use for diverse bone tissue engineering research applications.

Acknowledgements The author wishes to acknowledge Rita Araújo for advice given in primer design, Asmita Banerjee and Daniela Dopler for help with C2C12 cells, Anja Peterbauer for providing the fat-derived mesenchymal stem cells, and Heinz Redl for critical reviewing of the manuscript. This work was supported by PhD grant SFRH/BD/17049/2004 supported by Fundação para a Ciência e Tecnologia, project ElastM POCI/ CTM/57177/2004 supported by FEDER and Fundação para a Ciência e Tecnologia, as well as by the European STREP Project HIPPOCRATES (NMP3-CT-2003-505758). This work was carried out under the scope of the European NoE EXPERTISSUES (NMP3-CT-2004-500283).

\section{References}

Bessho K, Konishi Y, Kaihara S, Fujimura K, Okubo Y, Iizuka T (2000) Bone induction by Escherichia coli-derived 
recombinant human bone morphogenetic protein-2 compared with Chinese hamster ovary cell-derived recombinant human bone morphogenetic protein-2. $\mathrm{Br}$ J Oral Maxillofac Surg 38:645-649

Derynck R, Akhurst RJ, Balmain A (2001) TGF-beta signaling in tumor suppression and cancer progression. Nature Genet 29:117-129

Groppe J, Greenwald J, Wiater E, Rodriguez-Leon J, Economides AN, Kwiatkowski W, Affolter M, Vale WW, Belmonte JC, Choe S (2002) Structural basis of BMP signalling inhibition by the cystine knot protein Noggin. Nature 420:636-642

Hillger F, Herr G, Rudolph R, Schwarz E (2005) Biophysical comparison of BMP-2, ProBMP-2, and the free propeptide reveals stabilization of the pro-peptide by the mature growth factor. J Biol Chem 280:14974-14980

Israel DI, Nove J, Kerns KM, Moutsatsos IK, Kaufman RJ (1992) Expression and characterization of bone morphogenetic protein-2 in Chinese hamster ovary cells. Growth Factors 7:139-150

Israel DI, Nove J, Kerns KM, Kaufman RJ, Rosen V, Cox KA, Wozney JM (1996) Heterodimeric bone morphogenetic proteins show enhanced activity in vitro and in vivo. Growth Factors 13:291-300

Kirsch T, Nickel J, Sebald W (2000) BMP-2 antagonists emerge from alterations in the low-affinity binding epitope for receptor BMPR-II. EMBO J 19:3314-3324

Klösch B, Fürst W, Kneidinger R, Schuller M, Rupp B, Banerjee A, Redl H (2005) Expression and purification of biologically active rat bone morphogenetic protein-4 produced as inclusion bodies in recombinant Escherichia coli. Biotechnol Lett 27:1559-1564

Kubler NR, Reuther JF, Faller G, Kirchner T, Ruppert R, Sebald W (1998) Inductive properties of recombinant human BMP-2 produced in a bacterial expression system. Int J Oral Max Surg 27:305-309

Kubler NR, Wurzler K, Reuther JF, Faller G, Sieber E, Kirchner T, Sebald W (1999) EHBMP-2. Initial BMP analog with osteoinductive properties. Mund Kiefer Gesichtschir 3(Suppl 1):134-139

Li M, Chen C, Pu Q, Chen S (1998) Production of human recombinant bone morphogenetic protein-2A by high density culture of Escherichia coli with stationary dissolved oxygen fed-batch condition. Chin J Biotechnol 14:157-163

Long S, Truong L, Bennett K, Phillips A, Wong-Staal F, Ma H (2006) Expression, purification, and renaturation of bone morphogenetic protein-2 from Escherichia coli. Protein Expr Purif 46:374-378

Malafaya PP, Pedro AJ, Peterbauer A, Gabriel C, Redl H, Reis RL (2005) Chitosan particles agglomerated scaffolds for cartilage and osteochondral tissue engineering approaches with adipose tissue derived stem cells. J Mater Sci Mater Med 16:1077-1085

Miyazono K, Maeda S, Imamura T (2005) BMP receptor signalling: transcriptional targets, regulation of signal and signalling cross-talk. Cytokine Growth Fact Rev $16: 251-263$
Reddi AH (1981) Cell biology and biochemistry of endochondral bone development. Coll Relat Res 1:209-226

Reddi AH (1998) Role of morphogenetic proteins in skeletal tissue engineering and regeneration. Nature Biotechnol 16:247-252

Ruppert R, Hoffmann E, Sebald W (1996) Human bone morphogenetic protein 2 contains a heparin-binding site which modifies its biological activity. Eur J Biochem 237:295-302

Salgado AJ, Gomes ME, Chou A, Coutinho OP, Reis RL, Hutmacher DW (2002) Preliminary study on the adhesion and proliferation of human osteoblasts on starch-based scaffolds. Mater Sci Eng 20:27-33

Sambroock J, Fritsch EF, Maniatis T (1989) Molecular cloning: a laboratory manual, 2nd edn. Cold Spring Harbor Laboratory, New York

Sanger F, Nicklen S, Coulson AR (1977) DNA sequencing with chain-terminating inhibitors. Proc Natl Acad Sci USA 74:5463-5467

Sebald W, Nickel J, Zhang JL, Mueller TD (2004) Molecular recognition in bone morphogenetic protein (BMP)/receptor interaction. Biol Chem 385:697-710

Shi Y, Massague J (2003) Mechanisms of TGF-b signaling from cell membrane to the nucleus. Cell 113:685-700

Urist MR (1965) Bone: formation by autoinduction. Science 150:893-898

Vallejo LF, Brokelmann M, Marten S, Trappe S, CabreraCrespo J, Hoffmann A, Gross G, Weich HA, Rinas U (2002) Renaturation and purification of bone morphogenetic protein-2 produced as inclusion bodies in high-celldensity cultures of recombinant Escherichia coli. J Biotechnol 94:185-194

Vallejo LF, Rinas U (2004) Strategies for the recovery of active proteins through refolding of bacterial inclusion body proteins. Microb Cell Fact 3:11

Wang EA, Rosen V, D'Alessandro JS, Bauduy M, Cordes P, Harada T, Israel DI, Hewick RM, Kerns KM, LaPan P et al (1990) Recombinant human bone morphogenetic protein induces bone formation, Proc. Natl Acad Sci USA 87:2220-2224

Westerhuis RJ, van Bezooijen RL, Kloen P (2005) Use of bone morphogenetic proteins in Traumatology. Injury 36: 1405-1412

Wozney JM, Rosen V, Celeste AJ, Mitsock LM, Whitters MJ, Kriz RW, Hewick RM, Wang EA (1988) Novel regulators of bone-formation-Molecular clones and activities. Science 242:1528-1534

Wurzler KK, Emmert J, Eichelsbacher F, Kubler NR, Sebald W, Reuther JF (2004) Evaluation of the osteoinductive potential of genetically modified BMP-2 variants. Mund Kiefer Gesichtschir 8:83-92

Yang JH, Zhao L, Yang S, Wu SQ, Zhang J, Zhu TH (2003) Expression of recombinant human BMP-6 in Escherichia coli and its purification and bioassay in vitro. Sheng $\mathrm{Wu}$ Gong Cheng Xue Bao 19:556-60

Zuk PA, Zhu M, Ashjian P, De Ugarte DA, Huang JI, Mizuno $\mathrm{H}$, Alfonso ZC, Fraser JK, Benhaim P, Hedrick MH (2002) Human adipose tissue is a source of multipotent stem cells. Mol Cell Biol 13:4279-4295 